\title{
TEKNIK PIJATAN GULALI PADA PERHIASAN LOGAM
}

\author{
Achmad Fauzi ${ }^{1}$ (Institut Seni Indonesia Yogyakarta)
}

\begin{abstract}
The creation of these jewelery pieces comes from the longing for happy, happys and simple childhood memories. Cotton candy as a creating technique of metal jewelery is an expression of ideas inspired by the uniqueness and uniqueness of the shape of cotton candy massage. The cotton candy will be explored and developed with the power of imagination and creativity to create a unique piece of jewelry. The creation method used is in the form of the activity of extracting ideas, collecting data and references, analyzing the data using an aesthetic approach. The next method is the embodiment of the work that starts from the design, manufacture of models or patterns in accordance with the actual work. The technique used in the creation of this jewelry is the cast brass, stained and pave techniques. The works created were in the form of four sets of jewelry with four kinds of coloring and three works combined with natural stones, among others: red jasper stone, carnelian natural stone, red swarovski stone
\end{abstract}

Key Word: Memories, Massage, Cotton Candy, Art, Jewelry, Metal

\section{ABSTRAK}

Penciptaan karya seni perhiasan ini berasal dari kerinduan akan kenangan masa kecil yang ceria, bahagia dan sederhana. Pijatan gulali sebagai teknik penciptaan perhiasan logam adalah wujud pengekspresian ide atau gagasan yang terinspirasi dari keunikan dan kekhasan bentuk pijatan gulali. Pijatan gulali akan dieksplorasi dan dikembangkan dengan daya imajinasi serta kreativitas sehingga tercipta sebuah karya seni perhiasan yang unik. Metode penciptaan yang digunakan berupa aktivitas penggalian sumber ide, pengumpulan data dan referensi, analisis data menggunakan pendekatan estetis. Metode selanjutnya adalah perwujudan karya yang dimulai dari perancangan, pembuatan model atau pola sesuai dengan karya sebenarnya. Teknik yang digunakan dalam penciptaan perhiasan ini adalah teknik cor kuningan, patri dan pave. Karya yang diciptakan berupa empat set perhiasan dengan empat macam pewarnaan dan tiga karya dikombinasikan dengan batu alam antara lain: batu red jasper, batu natural carnelian, batu red swarovski.

Kata Kunci: Kenangan, Pijatan, Gulali, Seni, Perhiasan, Logam.

\section{PENDAHULUAN}

Indonesia memiliki berbagai macam jajanan tradisional yang harus dilestarikan keberadaannya. Jajanan tradisional merupakan salah satu ciri khas dan harta kebudayaan yang dimiliki oleh Indonesia. Tidak hanya dari sisi rasa, bentuk, keanekaragaman yang bermacam-macam dan menarik, tetapi juga dari warna-warnanya yang menggambarkan Negara Indonesia yang kaya berbagai macam kebudayaan dan suku bangsa. Dengan demikian, Indonesia memiliki makanan dan jajanan tradisional yang sangat beraneka ragam. Salah satunya adalah permen gulali. 
Permen gulali merupakan salah satu jajanan tradisional Indonesia yang cukup populer pada masanya. Ketika belum banyak permen atau lollipop kemasan seperti sekarang ini, anak-anak lebih menyukai membeli permen gulali yang dijajakan oleh pedagang keliling.

Seiring dengan perkembangan zaman dan kemajuan teknologi permen gulali sudah mulai sulit untuk ditemukan. Permen gulali mulai ditinggalkan oleh masyarakat karena dianggap tidak menarik dan sulit untuk mendapatkannya dibandingkan permen modern yang dikemas dengan desain yang lebih menarik dan mudah untuk mendapatkannya. Oleh karena itu, permen gulali tidak mampu mempertahankan eksistensinya.

Permen gulali juga bisa menjadi sebuah lorong waktu yang akan membawa kita ke masa ketika permen gulali begitu terkenal dan disukai banyak orang, seakan-akan kuliner menjadi jembatan penghubung berbagai peristiwa di masa lalu dan saat ini. Tak perlu lewat jajanan yang mahal, jajanan sederhana seperti gulali pun kita sudah bisa bernostalgia ke masa lalu. Dahulu gulali merupakan jajanan yang banyak digemari oleh banyak kalangan. Hampir semua orang pernah merasakannya. Rasanya yang manis membuat jajanan satu ini disukai terutama anak-anak.

Penulis mengambil salah satu jajanan tradisional gulali karena memiliki tekstur yang unik dan bentuknya yang menarik. Membuatnya saja masih sangat tradisional dan memiliki cita rasa serta warna yang khas. Membutuhkan keterampilan khusus dalam membuat adonan dan kreativitas dalam menciptakan bentuk jajanan ini. Penulis mengambil teknik pijatan gulali dikarenakan gulali dibentuk karena pijatan-pijatan tangan yang membuat permen ini sangat khas bentuknya dan juga sebagai salah satu jajanan tradisional yang sangat khas pada zaman dahulu.

Selain itu, penulis ingin bernostalgia mengenang kembali kerinduan masa kecil melalui jajanan tradisional gulali. Masih perlu ditanamkan rasa ingin mengetahui dan melestarikan budaya tradisional Indonesia. Oleh karena itu, penulis akan memvisualisasikan teknik pijatan gulali sebagai jajanan tradisional ke dalam sebuah karya perhiasan logam. Rumusan permasalahan dalam penciptaan ini adalah:

a. Bagaimanakah karakter/ciri khas dari pijatan gulali yang dapat dieksplorasi pada penciptaan karya perhiasan logam ini?

b. Bagaimanakah desain dan proses perwujudan perhiasan logam dengan teknik pijatan gulali yang khas dan unik?

\section{METODE PENCIPTAAN}

Dalam pembuatan perhiasan, metode penciptaan merupakan salah satu cara sistematis sebagai metode pengumpulan data untuk memperoleh objek acuan penciptaan dan menuangkan ide ke dalam karya seni. Metode penciptaan S.P. Gustami digunakan sebagai acuan dalam penciptaan karya seni. Menurut S.P. Gustami (2007: 329), penciptaan karya seni secara metodologis melalui tiga tahapan utama, yaitu:

a. Tahap Eksplorasi, yaitu aktivitas penjelajahan menggali sumber ide, pengumpulan data dan referensi, pengolahan dan analisis data menggunakan pendekatan estetis. Hasil dari penjelajahan atau analisis data dijadikan dasar untuk membuat rancangan atau desain.

b. Tahap Perancangan, yaitu memvisualisasikan hasil dari penjelajahan atau analisis data ke dalam berbagai sketsa rancangan (desain). Kumpulan rancangan (desain) tersebut kemudian diseleksi dan disempurnakan hingga 
menjadi rancangan final dan dibuatkan gambar kerjanya. Gambar kerja ini (proyeksi, potongan, detail, perspektif) nantinya menjadi acuan dalam proses perwujudan karya. Dalam tahap ini digunakan pendekatan estetik dan pendekatan ergonomik untuk menghasilkan rancangan yang menarik sekaligus praktis dalam pemakaiannya.

c. Tahap Perwujudan, yaitu mewujudkan rancangan terpilih atau final menjadi model sampai ditemukan kesempurnaan karya sesuai dengan desain atau ide. Model ini dapat dibuat dalam bentuk miniatur atau sesuai dengan karya yang sebenarnya. Jika hasil tersebut dianggap telah sempurna maka dapat dilanjutkan dengan pembuatan karya yang sesungguhnya (diproduksi). Proses seperti ini biasanya dilalui terutama dalam pembuatan karya-karya fungsional.

Selain metode penciptaan S.P. Gustami, digunakan juga pendekatan PracticeLed Research. Pendekatan Practice-Led Research adalah pendekatan yang berbasis pada sebuah penelitian yang diperoleh dari sebuah praktik. Praktik yang dimaksud dalam hal ini adalah praktik membuat karya seni.

$$
\text { Karya kreatif dalam lingkungan }
$$

universitas saat ini sering disebut practice-led research dan afiliasinya (Practice-Based Research, Creative Research atau Practice As Research). Istilah tersebut bermaksud untuk menggambarkan sebuah praktik yang dapat menghasilkan wawasan penelitian, seperti yang muncul dari karya kreatif atau pada dokumentasi dan teorisasi karya tersebut. Istilah Practice-Led Research dan afiliasinya digunakan untuk membuat dua pendapat tentang praktik yang biasanya tumpang tindih dan saling terkait: pertama, bahwa karya kreatif adalah bentuk dari penelitian dan menghasilkan sebuah penelitian yang jelas; kedua, untuk menyarankan bahwa praktik kreatif-pengetahuan yang dilatih milik praktisi kreatif dan proses yang dijalani pada saat mereka membuat karya-dapat menghasilkan wawasan penelitian khusus yang kemudian dapat digeneralisasi dan ditulis sebagai penelitian. (Smith dan T. Dean 2009 : 2-7).

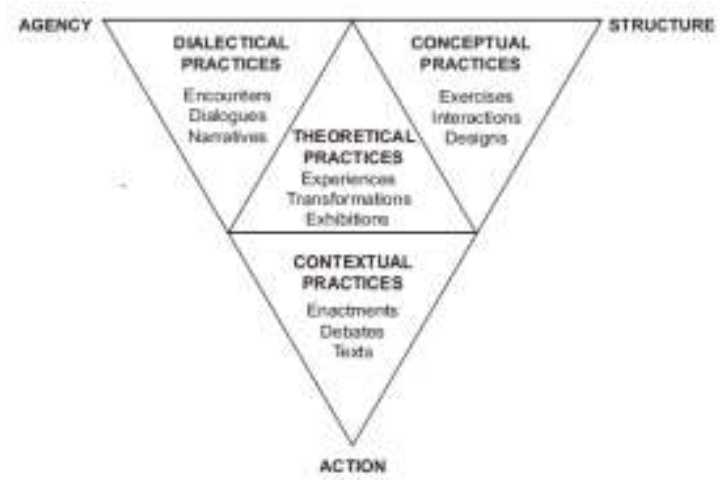

Gambar 1. Practice-Led Research: Sebuah Kerangka Praktik. (sumber: Practice-Led Research, Research-Led Practice in the Creative Arts, hal 49).

Gambar kerangka praktik di atas mendeskripsikan cakupan praktik penelitian yang dilakukan oleh seniman. Gambar tersebut menjelaskan berbagai cakupan wilayah penyelidikan yang terbuka untuk penelitian artistik yang dilakukan di studio sesuai aturan universitas. Bagian pusat yang mengikat empat jenis wilayah penelitian yaitu Theoretical Practices yang merupakan tempat dimana masalah penelitian dan isu ditemukan dan diselesaikan (Sullivan dalam Smith dan T. Dean 2009: 49). Para peneliti berbasis praktik kemudian bergerak keluar batasan luas imajinasi dan intelektual. Jika dilihat dari hubungan dengan sekitarnya, cara pandang dan praktik yang berbeda muncul sebagai permintaan dan berbalik arah pada berbagai sumber dalam eksplorasi agency, structure, dan action. Dengan demikian, wilayah yang lebih luas dinamakan conceptual, dialectical, dan contextual practices yang mencakup kegiatan pada aktivitas penelitian.

Conceptual Practices adalah bagian terpenting untuk berpikir dan membuat tradisi 
dimanapun seniman merumuskan bentuk hingga konsep pada pembuatan karya yang menjadi bagian dari proses penelitian. Di sinilah seniman terlibat dalam praktik yang menggunakan kapasitas 'berpikir setengah matang' memanfaatkan persebaran pengandaian kognitif dengan pengetahuan visual. Dialectical Practices adalah bentuk penyelidikan seniman untuk mengeksplorasi keunikan proses, memaknai sebuah pengalaman yang dirasakan, dihidupi, disusun ulang, dan diartikan kembali. Hal ini mungkin personal atau umum dan mungkin merupakan hasil dari berhadapan dengan karya seni. Oleh karena itu, sebuah makna karya seni telah 'dibuat' dari transaksi dan narasi yang menyatu dan memiliki kekuatan dan agen untuk membawa perubahan pada tingkat individu atau bahkan masyarakat. Seniman di sini menggunakan kapasitas kognitif dari sebuah seni sebagai proses sosial yang dimediasi dan proses dari 'berpikir dengan bahasa' dimana gambar dan objek adalah sebuah tulisan berbentuk kode yang membutuhkan analisis dan dialog untuk menciptakan dan mengkomunikasikan makna. Contextual Practices, mencerminkan tradisi lama suatu seni sebagai kritikan dari bentuk penyelidikan yang bertujuan untuk membawa perubahan sosial. Praktisi seni kontekstual memanfaatkan proses kognitif dengan penjelasan terbaik sebagai 'berpikir pada aturan' hal itu merupakan situasional dan memanfaatkan teks visual, isu, debat, dan hasrat yang fokus pada bagian kecil, tetapi cakupannya luas.

Hubungan dari metode penciptaan dan Practice-Led Research tersebut dapat dilihat dari proses atau praktik adalah suatu komponen penting dalam pembuatan karya seni. Proses penciptaan dijelaskan dalam metode penciptaan, yang kemudian metode tersebut menghasilkan penelitian bagi para senimannya.
Berikut beberapa data yang menjadi sumber penciptaan karya:

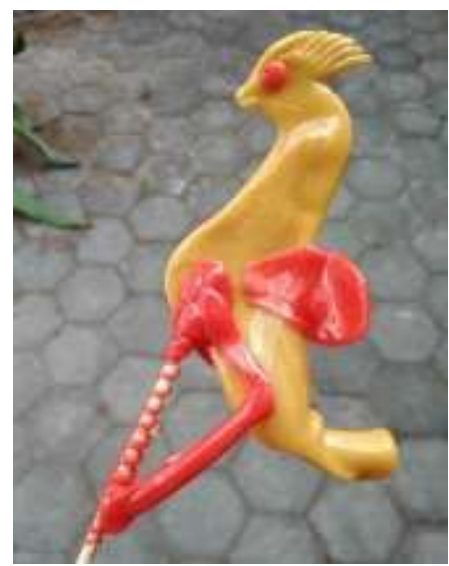

Gambar 2. Permen Gulali Bentuk Ayam, 2018

(Foto : Achmad Fauzi, 5 November 2018, 07:15)

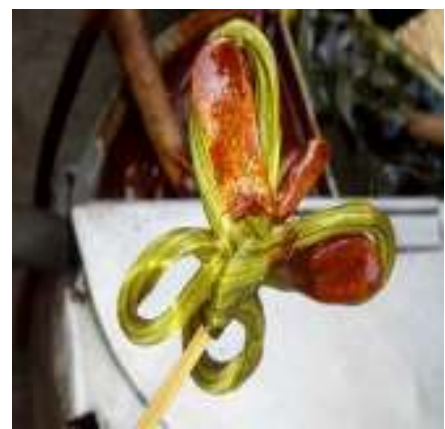

Gambar 3. Permen Gulali Bentuk Kupu-kupu, 2016. (sumber: https://ramesia.com/cara-membuat-gulalitarik/, 1 Februari 2019, 22:05)

\section{PEMBAHASAN}

\section{a. Proses Penciptaan}

Proses penciptaan karya pada dasarnya tidak terlepas dari data acuan berupa data teoritik dan bentuk visual foto atau gambar karya. Data acuan berfungsi sebagai pendukung untuk mencapai hasil karya yang sesuai dengan ide dan tema yang dipilih serta membantu eksplorasi mengasah kreativitas dan sensitivitas dalam berkarya seni. Data diperoleh melalui pengamatan langsung, buku dan internet. Berikut beberapa data acuan yang menjadi sumber inspirasi karya: 


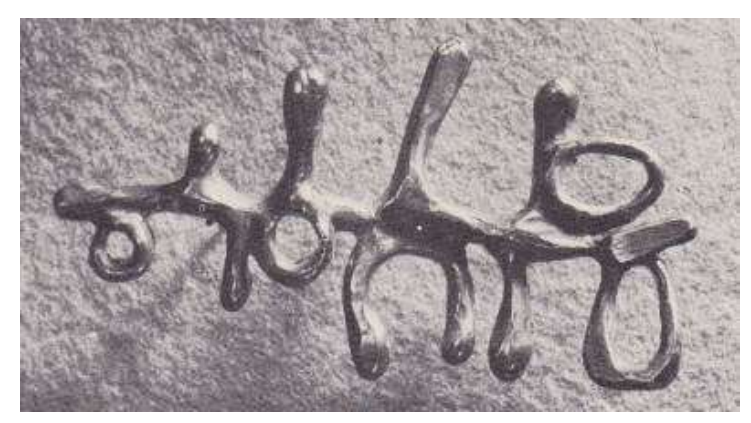

Gambar 4. PIN. Silicon bronze, "Growth". 21/4" long, Lost wax, by Robert Coleman. (sumber: Chouate, Sharr., 1996. Hal. 126. Crown Publishers, Inc., New York.)

Gambar 4 adalah data acuan perhiasan milik Robert Coleman berjudul "Growth". Robert menggunakan silikon sebagai molding atau cetakan sedangkan model atau master cetakannya menggunakan lilin. Kemudian menggunakan bahan perunggu untuk mencetak perhiasan ini menjadi sebuah pin. Perhiasan ini memiliki bentuk yang unik, menyerupai garis yang membentuk alur yang tidak beraturan tetapi sangat dinamis dan memiliki keseimbangan. Hal inilah yang menarik penulis sebagai inspirasi menciptakan perhiasan yang bersumber dari bentuk ayam gulali. Gulali memiliki bentuk yang ulet dan dapat dibentuk dengan alur yang kita inginkan. Alur-alur yang meliak-liuk inilah yang penulis angkat untuk ditonjolkan pada bentuk perhiasan.

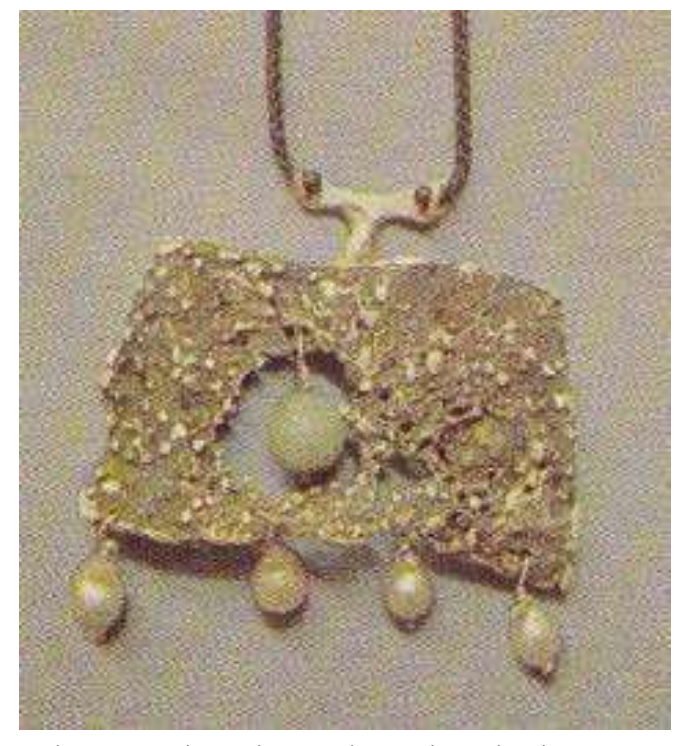

Gambar 5. Sterling silver with pearls and jade, Lost wax, by John Leary. (sumber: Chouate, Sharr., 1996. Hal. 87. Crown Publishers, Inc., New York.)
Gambar 5 adalah data acuan perhiasan milik John Leary terbuat dari perak dihiasi dengan mutiara dan giok. John membuat perhiasannya menggunakan silikon sebagai cetakannya dan lilin sebagai modelnya. Perhiasan ini memberikan inspirasi penulis untuk menggunakan kombinasi sebuah batu di dalam menciptakan perhiasan. Batu pada perhiasan dapat diletakkan sebagai "point of interest" atau dapat menjadi pelengkap dan pemanis. Selain itu data acuan ini memberikan inspirasi motif berlubang pada permukaan perhiasan. Lubang inilah yang dapat menjadi suatu hal yang menarik untuk dieksplorasi menjadi sentuhan dalam sebuah desain perhiasan.

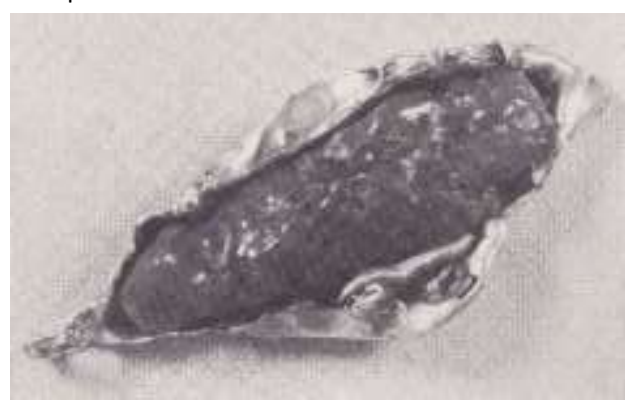

Gambar 6. Pendant. Silver with botryoidal jade, Lost wax, by Edna Sayre. (sumber: Chouate, Sharr., 1996. Hal. 120. Crown Publishers, Inc., New York.)

Gambar 6 adalah data acuan perhiasan milik Edna Sayre terbuat dari perak dihiasi dengan giok botryoidal. Data acuan ini memiliki persamaan ide yaitu menggunakan teknik pijatan dalam penciptaan karya perhiasan. Perbedaan dengan rancangan karya yang penulis ciptakan yaitu pijatan yang penulis maksud adalah pijatan dari teknik pembuatan permen gulali, sedangkan perhiasan milik Edna Sayre berbentuk menyerupai pijatan untuk memberikan desain yang unik dan beda. Teknik pijatan-pijatan inilah yang akan menjadi ciri khas dari perhiasan yang penulis ciptakan.

Berikut adalah perencanaan karya yang akan diawali dengan pembuatan sketsa terpilih. 
a. Set Perhiasan I

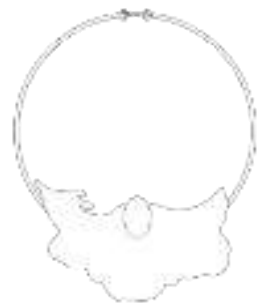

Gambar 7. Rancangan Karya I (Sketsa: Achmad Fauzi, 2018)

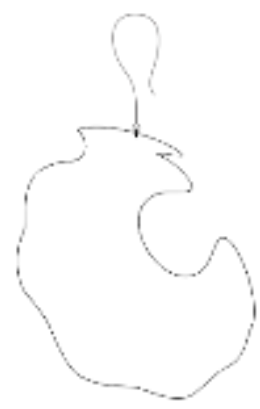

Gambar 8. Rancangan Karya II (Sketsa: Achmad Fauzi, 2018)

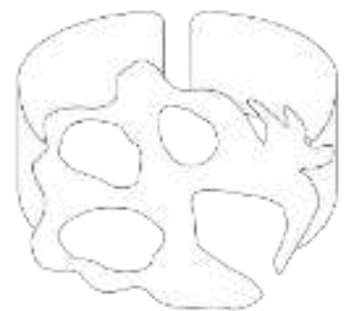

Gambar 9. Rancangan Karya III (Sketsa: Achmad Fauzi, 2018)

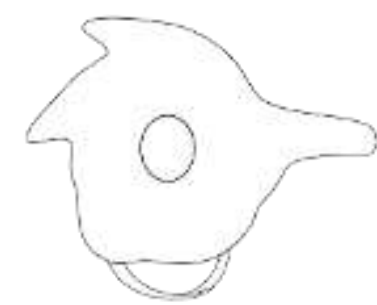

Gambar 10. Rancangan Karya IV (Sketsa: Achmad Fauzi, 2018) b. Set Perhiasan II

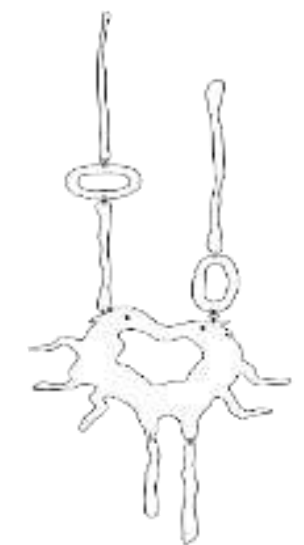

Gambar 11. Rancangan Karya V

(Sketsa: Achmad Fauzi, 2018)

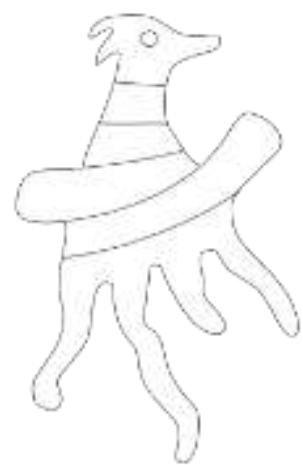

Gambar 12. Rancangan Karya VI (Sketsa: Achmad Fauzi, 2018)

c. Set Perhiasan III

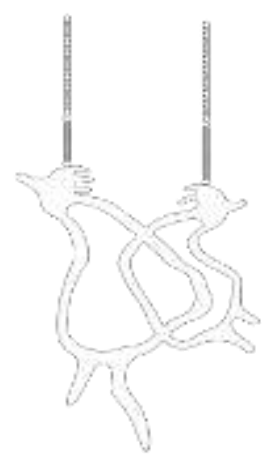

Gambar 13. Rancangan Karya VII (Sketsa: Achmad Fauzi, 2018) 


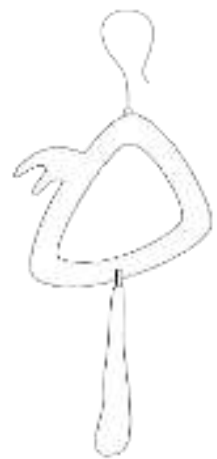

Gambar 14. Rancangan Karya VIII (Sketsa: Achmad Fauzi, 2018)

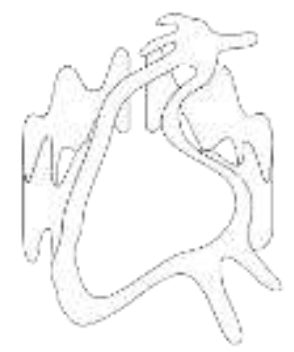

Gambar 15. Rancangan Karya IX (Sketsa: Achmad Fauzi, 2018)

d. Set Perhiasan IV

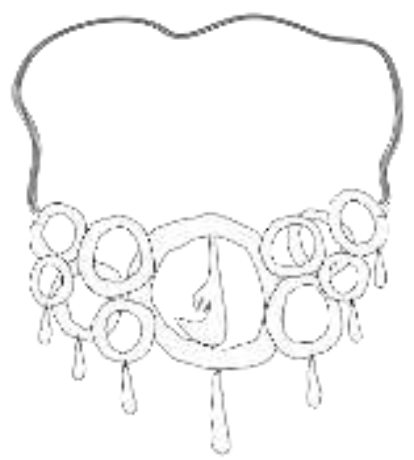

Gambar 16. Rancangan Karya X (Sketsa: Achmad Fauzi, 2018)

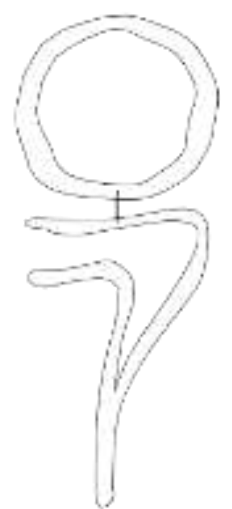

Gambar 17. Rancangan Karya XI

(Sketsa: Achmad Fauzi, 2018)

\section{b. Perwujudan Karya Perhiasan Logam}

Setelah proses perancangan, langkah selanjutnya adalah merealisasikan rancangan menjadi karya jadi. Proses perwujudan karya dilakukan dengan tahapan-tahapan sebagai berikut:

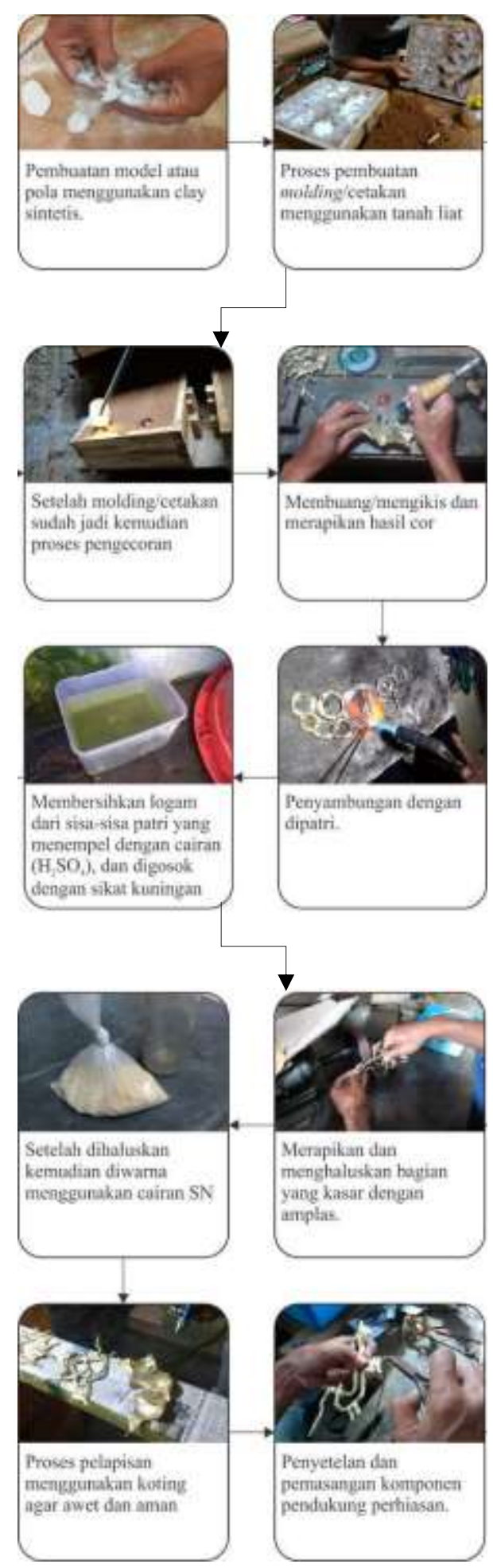




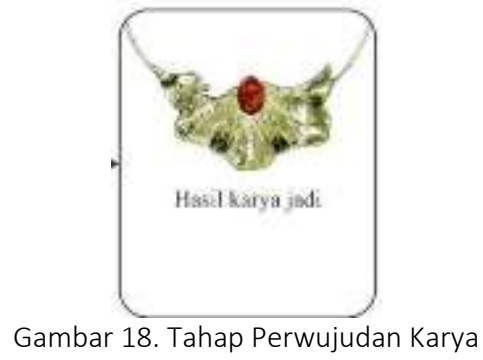

\section{c. Karya Perhiasan Logam dengan Teknik Pijatan} Gulali

Hasil karya perhiasan logam dengan teknik pijatan gulali ini berjumlah empat set dengan total jumlah sebelas karya diantaranya berupa kalung, anting-anting, gelang, giwang, cincin dan bros. Beberapa hasil karya dapat dilihat pada gambar berikut ini.

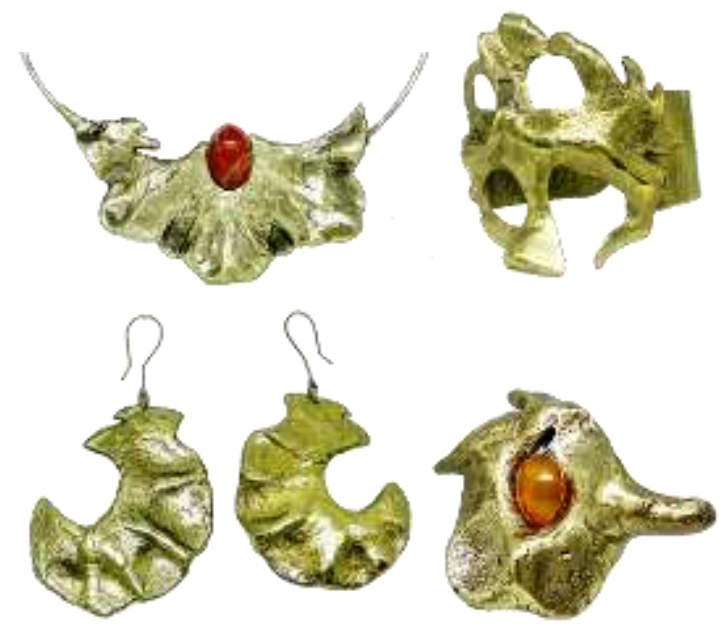

Gambar 19. Set Perhiasan I
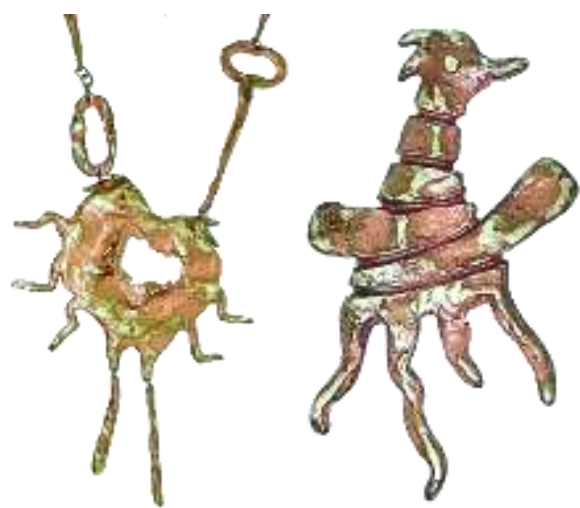

Gambar 20. Set Perhiasan II
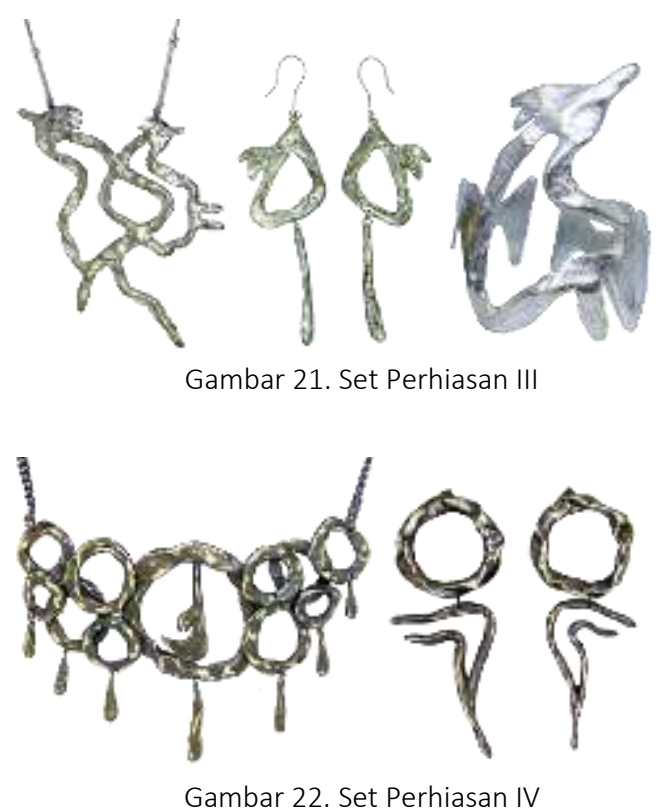

PENUTUP

Berdasarkan rangkaian proses penciptaan karya seni perhiasan dengan teknik pijatan gulali, ada beberapa hal yang dapat disimpulkan sebagai berikut; 1) Permen gulali bisa menjadi sebuah lorong waktu yang akan membawa kita ke masa ketika permen gulali begitu terkenal dan disukai banyak orang, seakan-akan kuliner menjadi jembatan penghubung berbagai peristiwa di masa lalu dan saat ini; 2) Proses penciptaan karya seni perhiasan ini dimulai dengan tahap eksplorasi, yaitu mengumpulkan data dan referensi yang berkaitan dengan teknik pijatan gulali. Hasil dari pengumpulan data tersebut kemudian diolah dan dianalisis menggunakan pendekatan estetika untuk menciptakan bentuk rancangan karya berbagai jenis perhiasan yang lebih kreatif dan inovatif; 3) Penciptaan karya seni perhiasan dengan teknik pijatan gulali menghasilkan empat set perhiasan dan total jumlah sebelas karya, terdiri dari: kalung, anting, gelang, cincin, bros, dan giwang. 
DAFTAR PUSTAKA

Anonim. 2010. Bernostalgia Dengan Gulali, (Online), https://djamandoeloe.com, diakses tanggal 19 Desember 2016).

Choate, Sharr. 1966. Creative Casting, New York: Crown Publishers.

Febrian Wisnu Adi, Studi Eksperimen finishing perhiasan kuningan dengan Perpaduan Elektreoniplanting dan Patinasi. Corak: Jurnal Seni Kriya, http://journal.isi.ac.id/index.php/corak/ar ticle/view/2662

Gustami, SP., 2007. Butir-Butir Mutiara Estetika Timur: Ide Dasar Penciptaan Karya, Yogyakarta: Pratista.
Metcalf Juror, Bruce., 2012. Showcase 500 Rings. New York: Lark Crafts.

, Timbul Raharjo., 1991. Modul Praktek Teknik Produksi Kriya Logam. Yogyakarta: Institut Seni Indonesia Yogyakarta.

Rispul., 2016. Modul Praktek Dasar Mengukir Logam. Yogyakarta: Institut Seni Indonesia Yogyakarta.

Smith, Hazel dan Dean, Roger T. 2009. Practice-Led Research, Research-Led Practice in the Creative Arts. Edinburgh: Edinburgh University Press.

\section{WEBTOGRAFI}

https://ramesia.com/cara-membuat-gulalitarik/ 